\title{
Synthesis, Molecular Docking Studies and Antifungal Activity Evaluation of New Thiazolyl-methylen-1,3,4-oxadiazolines as Potential Lanosterol 14 $\alpha$-demethylase Inhibitors
}

\author{
SMARANDA ONIGA ${ }^{1}$, CATALIN ARANICIU1*, GABRIEL MARC ${ }^{2}$, LIVIA UNCU ${ }^{3,4}$, MARIANA PALAGE ${ }^{1}$, OVIDIU ONIGA ${ }^{2}$ \\ ${ }^{1}$ Iuliu Hatieganu University of Medicine and Pharmacy, Faculty of Pharmacy, Department of Therapeutic Chemistry, \\ 12 Ion Creanga Str., 400010 Cluj Napoca, Romania \\ 2 Iuliu Hatieganu University of Medicine and Pharmacy, Faculty of Pharmacy, Department of Pharmaceutical Chemistry, \\ 41 Victor Babes Str., 400012, Cluj Napoca, Romania \\ ${ }^{3}$ Pharmaceutical Chemistry and Toxicology, Faculty of Pharmacy, Nicolae Testemitanu State University of Medicine and Pharmacy \\ Chisinau, Republic of Moldova \\ ${ }^{4}$ Scientific Center of Drug Research, Nicolae Testemitanu State University of Medicine and Pharmacy Chisinau, Republic of \\ Moldova
}

Considering the well-established antifungal activity of azole compounds, a new series of thiazolyl-methylen1,3,4-oxadiazolines derivatives were designed and synthesized as lanosterol-demethylase inhibitors. The final compounds were screened for antifungal activity against the Candida albicans ATCC 90028 strain. Molecular docking studies were performed to investigate the interaction modes between the compounds

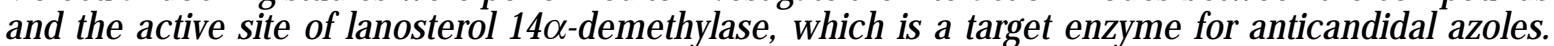
Theoretical ADME predictions were also calculated for the final compounds $\mathbf{5 a - h}$.

Keywords: Thiazolyl-methylen-1,3,4-oxadiazolines, Candida albicans, lanosterol 14 $\alpha$-demethylase

Candida species represent the most common fungal pathogens that affecthumans and the mortality associated with invasive mycosis increased in the last decade. Candida albicans is among the most diagnosed fungal species in clinical samples. This fungal strain lives as a commensal in the microbiome of healthy individuals, butcan propagate as a pathogen in immunocompromised patients [1]. The azoles are the most widely used class of antifungal drugs. These compounds affect the integrity of fungal membranes, altering their morphology and inhibiting growth. This is achieved by inhibiting ergosterol biosynthesis via the inhibition of cytochrome P450's enzyme 14- $\alpha$ demethylase, which catalyzes the conversion of lanosterol to ergosterol. However, since this enzyme is similar to one found in the human liver, drug interactions due to metabolism can occur [2,3].

Prolonged use of azoles as antifungal agents has resulted in the emergence of drug resistance among certain fungal strains [4]. A novel strategy of generating a new class of azole based antifungal agents is the merger of two or more biologically important azole scaffolds, to achieve a target compound with improved activity [5-7]. To this end we chose two biologically important azole scaffolds: thiazole and 1,3,4-oxadiazole and fused them together into one hybrid molecule taking account that compounds comprising each of these type of azoles are associated with a broad spectrum of biological properties, including antifungal activity [8-14].

Following our research of novel azole based antimicrobial agents [15-17], we propose here the synthesis of some novel thiazolyl-methylen-1,3,4oxadiazolines derivatives as possible antifungal agents. To investigate the interaction modes between the compounds and active site of lanosterol 14-5 $\alpha$-demethylase, a molecular docking study was performed.

\section{Experimental part \\ Chemistry}

Melting points were determined using open capillary tube method and are uncorrected. The purity of the synthesized compounds was verified by thin layer chromatography (TLC) and was carried out on pre-coated Silica Gel 60F254 sheets using heptan-ethyl-acetate 7:3 as developpant and UV absorption for visualization.

The ${ }^{1} \mathrm{H}$ NMR spectra were recorded at room temperature on a Bruker Avance NMR spectrometer operating at 500 $\mathrm{MHz}$. Chemical shift values were reported relative to tetramethylsilane (TMS) as internal standard. The samples were prepared by dissolving the synthesized powder of the compounds in DMSO $d 6$ ( $\delta \mathrm{H}=2.51 \mathrm{ppm})$ as solvent and the spectra were recorded using a single excitation pulse of $12 \mu \mathrm{s}$. GC-MS analyses were performed with an Agilent gas chromatograph 6890 equipped with an apolar Macherey Nagel Permabond SE 52 capillary column. Elemental analysis was registered with a Vario El CHNS instrument.

All new compounds yielded spectral data consistent with the proposed structure and microanalysis within $0.4 \%$ of the theoretical values.

\section{Synthesis of ethyl 2-(aryl)-thiazole-4-yl-acetate (2a-b) - general procedure \\ Compounds $2 \mathbf{a}-\mathbf{b}$ were synthesized by refluxing a mixture of benzothioamide or 4-methyl-benzothioamide ( $30 \mathrm{mmol}$ ) with ethyl 4-bromo-3-oxobutanoate $(30 \mathrm{mmol}$ ) in absolute ethanol ( $30 \mathrm{~mL}$ ) for $1 \mathrm{~h}$. After cooling, the mixture was poured in cold water and the oily liquid formed was separated by ether extraction and filtration over anhydrous sodium sulfate.}


2a: ethyl (2-phenyl-1,3-thiazol-4-yl)acetate: $\mathrm{C}_{13} \mathrm{H}_{13} \mathrm{NO}_{2} \mathrm{~S}$; Yield 80\%, MS (El, 70eV): $\mathrm{m} / \mathrm{z} 248(\mathrm{M}+)$. ${ }^{1} \mathrm{HNMR}$ (BMSO$\mathrm{d} 6, \delta, \mathrm{ppm}) \delta: 7-7.94,5 \mathrm{H}$ phenyl, $7.1(\mathrm{~s}, 1 \mathrm{H}$, thiazole-5), $4.04\left(\mathrm{q}, 2 \mathrm{H}, \mathrm{CH}_{2}, \mathrm{OCH}_{2} \mathrm{CH}_{3}\right), 3.96\left(\mathrm{~s}, 2 \mathrm{H}, \mathrm{CH}_{2}\right) 1.26$ (t, 3H, $\left.\mathrm{CH}_{3}, \mathrm{OCH}_{2} \mathrm{CH}_{3}\right)$.

2b: ethyl 2-(2-(p-tolyl)thiazol-4-yl)acetate: $\mathrm{C}_{14} \mathrm{H}_{1} \mathrm{NO}_{2} \mathrm{~S}$; Yield 75\%. MS (El, 70eV): m/z 262 (M+). 'HNMR (DMSO$\mathrm{d} 6, \delta, \mathrm{ppm}) \delta: 7.26-7.96,4 \mathrm{H}$ phenyl, $7.06(\mathrm{~s}, 1 \mathrm{H}$, thiazole5), $4.04\left(\mathrm{q}, 2 \mathrm{H}, \mathrm{CH}_{2}, \mathrm{OC}_{2} \mathrm{H}_{5}\right), 4.06\left(\mathrm{~s}, 2 \mathrm{H}, \mathrm{CH}_{2}\right) 2.34(\mathrm{~s}, 3 \mathrm{H}$, $\left.\mathrm{CH}_{3}\right), 1.21\left(\mathrm{t}, 3 \mathrm{H}, \mathrm{CH}_{3}, \mathrm{OCH}_{2} \mathrm{CH}_{3}\right)$.

Synthesis of 2-(2-arylthiazol-4-yl)acetohydrazides $3 a-b$ - general procedure: $20 \mathrm{mmol}$ of compound $2 a$ or $2 b$ and $1 \mathrm{~mL}$ of hydrazine hydrate were refluxed for $2 \mathrm{~h}$ in absolute ethanol $(10 \mathrm{~mL})$. The reaction mixture was cooled and the crystalline mass obtained was recrystallised from ethanol.

3a: 2-(2-phenylthiazol-4-yl)acetohydrazide $\mathrm{C}_{11} \mathrm{H}_{11} \mathrm{~N}_{3} \mathrm{~S}$; Yield 70\%. m.p. $128-130^{\circ} \mathrm{C}$. MS (El, 70eV): $\mathrm{m} / \mathrm{z} 233$ (M). ${ }^{3} \mathrm{H}$ NMR (DMSO-d6, $\delta, \mathrm{ppm}) \delta: 9.21(\mathrm{~s}, 1 \mathrm{H}, \mathrm{NH}), 7.16-7.97,5 \mathrm{H}$ phenyl $7.26\left(\mathrm{~s}, 1 \mathrm{H}\right.$, thiazole-5), $4.73\left(\mathrm{~s}, 2 \mathrm{H}, \mathrm{NH}_{2}\right), 4.04(\mathrm{~s}$, $\left.2 \mathrm{H}, \mathrm{CH}_{2}\right)$.

3b: 2-(2-(p-tolyl) thiazol-4-yl)acetohydrazide: $\mathrm{C}_{11} \mathrm{H}_{2} \mathrm{~N}_{3} \mathrm{~S}$, Yield 73\%. m.p. $133-135^{\circ} \mathrm{C}$. MS (El, 70eV): $\mathrm{m} / \mathrm{z} 247$ (M) ${ }^{3} \mathrm{H}$ NMR (DMSO-d6, $\delta$, ppm) $\delta: 9.21(\mathrm{~s}, 1 \mathrm{H}, \mathrm{NH}), 7.3-7.8,4 \mathrm{H}$ phenyl, $7.3\left(\mathrm{~s}, 1 \mathrm{H}\right.$, thiazole-5), $4.73\left(\mathrm{~s}, 2 \mathrm{H}, \mathrm{NH}_{2}\right), 4.08(\mathrm{~s}$, $\left.2 \mathrm{H}, \mathrm{CH}_{2}\right), 2.34\left(\mathrm{~s}, 3 \mathrm{H}, \mathrm{CH}_{3}\right)$.

Synthesis of 2-arylthyazol-4-yl-acetohydrazones 4ah - general procedure: equimolar quantities of 2-(2arylthiazol-4-yl)acetohydrazides $3 a-b$ and various aromatic or heteroaromatic aldehydes were refluxed in absolute ethanol for $2 \mathrm{~h}$. The solid product, formed after cooling, was filtered and dried. The crude solid was re-crystallised from ethanol

4a: N'-(4-chlorobenzylidene)-2-(2-phenylthiazol-4yl)acetohydrazide $\mathrm{C}_{18} \mathrm{H}_{14} \mathrm{CIN}_{3} \mathrm{OS}$; Yield 82\%. m.p. 142$144^{\circ} \mathrm{C}$, MS (El, 70eV): $\mathrm{m} / \mathrm{z}^{14} 357^{3}(\mathrm{M}+2)$. ${ }^{1} \mathrm{H}$ NMR (DMSO-d6, $\delta$, ppm) $\delta: 11.49(\mathrm{~s} 1 \mathrm{H}, \mathrm{NH}), 8.51$ (s $1 \mathrm{H},-\mathrm{N}=\mathrm{CH}-\mathrm{Ph}), 7.49-$ 7.94, $9 \mathrm{H}$ (5H phenyl, $4 \mathrm{H} \mathrm{p}$-Cl-phenyl), 7.0 (s $1 \mathrm{H}$, thiazole5), $4.2\left(\mathrm{~s}, 2 \mathrm{H}, \mathrm{CH}_{2}\right)$.

$4 \mathbf{b}: N^{\prime}$-(4-bromobenzylidene)-2-(2-phenylthiazol-4yl) acetohydrazide $\mathrm{C}_{1} \mathrm{H}_{1} \mathrm{BrN}_{3} \mathrm{OS}$; Yield 85\%. m.p. 161$164{ }^{\circ} \mathrm{C}$, MS (El, 70eV): $\mathrm{m}^{\mathrm{m}} / \mathrm{z}^{18} 401^{3}(\mathrm{M})$. ${ }^{1} \mathrm{H}$ NMR (DMSO-d6, $\delta$, ppm) $\delta: 11.34$ (s $1 \mathrm{H}, \mathrm{NH}), 8.51$ (s $1 \mathrm{H},-\mathrm{N}=\mathrm{CH}-\mathrm{Ph}), 7.24-$ 7.97, $9 \mathrm{H}$ (5H phenyl, $4 \mathrm{H}$ p-Br-phenyl), 7.1 (s $1 \mathrm{H}$, thiazole5), $4.02\left(\mathrm{~s}, 2 \mathrm{H}, \mathrm{CH}_{2}\right)$

4c: N'-(4-nitrobenzylidene)-2-(2-phenylthiazol-4yl)acetohydrazide $\mathrm{C} \mathrm{H} N \mathrm{~N}$ O S; Yield $85 \%$. m.p. $202-204^{\circ} \mathrm{C}$ MS (El, 70eV): $\mathrm{m} / \mathrm{z} 366$ ('M). ${ }^{3}$ H NMR (DMSO-d6, $\left.\delta, p p m\right) \delta$ : $11.4(\mathrm{~s} 1 \mathrm{H}, \mathrm{NH}), 8.48$ (s $1 \mathrm{H},-\mathrm{N}=\mathrm{CH}-\mathrm{Ph}), 7.3-7.97,9 \mathrm{H}(5 \mathrm{H}$ phenyl, 4H p-NO ${ }_{2}$-phenyl), 7.24 ( $\mathrm{s} \mathrm{H}$, thiazole-5), 4.00 (s, $\left.2 \mathrm{H}, \mathrm{CH}_{3}\right)$

4d : 2-(2-phenylthiazol-4-yl)-N'-((2-phenylthiazol-4yl)methylene)acetohydrazide $\mathrm{C}_{1} \mathrm{H}_{1} \mathrm{~N} \mathrm{OS}_{2}$, Yield $70 \%$ m.p. 133-136 $\mathrm{C}$, MS (El, 70eV): $\mathrm{m} / \mathrm{z} 405(\mathrm{M}+1)$. ${ }^{\prime}$ H NMR (DMSOd6, $\delta, \mathrm{ppm}$ ) $\delta: 11.58$ (s $1 \mathrm{H}, \mathrm{NH}), 8.65$ (s $1 \mathrm{H},-\mathrm{N}=\mathrm{CH}-\mathrm{Ph}$ ), 7.47-8.03, 10H (2 phenyl), 7.24 (s 2H, 2 thiazole-5), 4.02 (s, $\left.2 \mathrm{H}, \mathrm{CH}_{2}\right)$

4e: $N$ '-(2-chlorobenzylidene)-2-(2-(p-tolyl)thiazol-4yl) acetohydrazide $\mathrm{C}_{10} \mathrm{H}_{10} \mathrm{CIN}_{3} \mathrm{OS}$, Yield 78\%. m.p. 138$140^{\circ} \mathrm{C}$, MS (El, 70eV): $\mathrm{m} / \mathrm{z}^{16} 371^{3}(\mathrm{M}+2)$. ${ }^{1 \mathrm{H}}$ NMR (DMSO-d6, $\delta$, ppm) $\delta: 10.86(\mathrm{~s} 1 \mathrm{H}, \mathrm{NH}$ ), 8.63 (s $1 \mathrm{H},-\mathrm{N}=\mathrm{CH}-\mathrm{Ph}), 7.27-$ $7.79,8 \mathrm{H}$ ( $4 \mathrm{H}$ tolyl, $4 \mathrm{H} \mathrm{o-Cl-phenyl),} 7.12$ (s $1 \mathrm{H}$, thiazole-5), $3.96\left(\mathrm{~s}, 2 \mathrm{H}, \mathrm{CH}_{2}\right), 2.38\left(\mathrm{~s}, 3 \mathrm{H}\right.$, tolyl- $\left.\mathrm{CH}_{3}\right)$.

4f: $N^{\prime}$-( 4-fluorobenzylidene)-2-(2-( $p$-tolyl)thiazol-4yl) acetohydrazide $\mathrm{C}, \mathrm{H}, \mathrm{FN}, \mathrm{OS}$, Yield $80 \%$. m.p. $252-255^{\circ} \mathrm{C}$, MS (El, 70eV): m/z 354 (M+1). ${ }^{1} \mathrm{H}$ NMR (DMSO-d6, $\left.\delta, \mathrm{ppm}\right)$ $\delta: 11.49$ (s 1H, NH), 8.55 (s $1 \mathrm{H},-\mathrm{N}=\mathrm{CH}-\mathrm{Ph}), 7.24-7.79,8 \mathrm{H}$ (4H tolyl, 4H p-F-phenyl), 7.1 (s 1H, thiazole-5), $3.96(\mathrm{~s}, 2 \mathrm{H}$, $\left.\mathrm{CH}_{2}\right), 2.34\left(\mathrm{~s}, 3 \mathrm{H}\right.$, tolyl- $\left.-\mathrm{CH}_{3}\right)$.

REV.CHIM.(Bucharest) $70 \diamond$ No. $10 \diamond 2019$

http://www.revistadechimie.ro 4g: N'-(2-methoxybenzylidene)-2-(2-(p-tolyl)thiazol-4yl) acetohydrazide $\mathrm{C} \mathrm{H}_{\mathrm{N}} \mathrm{O} \mathrm{S}$; Yield $78 \%$. m.p. $142-145^{\circ} \mathrm{C}$, MS (El, 70eV): $\mathrm{m} / \mathrm{z} 366$ ('M+1). ${ }^{1} \mathrm{H}$ NMR (DMSO-d6, $\delta, \mathrm{ppm}$ ) $\delta: 10.75(\mathrm{~s} 1 \mathrm{H}, \mathrm{NH}), 8.58$ (s $1 \mathrm{H},-\mathrm{N}=\mathrm{CH}-\mathrm{Ph}), 7.04-7.86,9 \mathrm{H}$

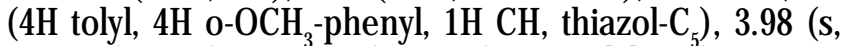
$\left.2 \mathrm{H}, \mathrm{CH}_{2}\right), 3,7\left(\mathrm{~s} 3 \mathrm{H}, \mathrm{OCH}_{3}\right), 2.34\left(\mathrm{~s}, 3 \mathrm{H} \text {, tolyl- } \mathrm{CH}_{3}\right)^{2}$.

4h: $N^{\prime}-(2,4-d i c h l o r o b e n z y l i d e n e)-2-(2-(p-t o l y l)$ thiazol-4yl) acetohydrazide $\mathrm{C}_{19} \mathrm{H}_{15} \mathrm{Cl} \mathrm{N}_{3} \mathrm{OS}$; Yield $78 \%$. m.p. 289$291^{\circ} \mathrm{C}$, MS (El, 70eV): $\left.\mathrm{m} / \mathrm{z}^{15} 405^{3} \mathrm{M}+2\right)$. ${ }^{1} \mathrm{H}$ NMR (DMSO-d6, $\delta, \mathrm{ppm}) \delta: 11.33(\mathrm{~s} 1 \mathrm{H}, \mathrm{NH}), 8.59$ (s $1 \mathrm{H},-\mathrm{N}=\mathrm{CH}-\mathrm{Ph}), 7.26-$ 7.86, $7 \mathrm{H}$ (4H tolyl, 3H 0,p-di-Cl-phenyl), 7.06, (s $1 \mathrm{H} \mathrm{CH}$ thiazole $\left.\mathrm{C}_{5}\right), 4.04\left(\mathrm{~s}, 2 \mathrm{H}, \mathrm{CH}_{2}\right), 2.34\left(\mathrm{~s}, 3 \mathrm{H}\right.$, tolyl- $\left.\mathrm{CH}_{3}\right)$

Synthesis of 1-(2-(aryl)-5-((2-arylthiazol-4yl)methyl)-1,3,4-oxadiazol-3(2H)-yl)ethanones 5a-hgeneral procedure: $1 \mathrm{mmol}$ of $N^{\prime}$-(aryl)-2-(2-arylthiazol4-yl)acetohydrazides $4 a-h$ were refluxed with acetic anhydride $(3 \mathrm{~mL})$ for $2 \mathrm{~h}$. After cooling, the reaction mixture was poured into ice cold water. The obtained precipitate was filtered off, washed with water and re-crystallised from ethanol to give the compounds $5 a-h$.

5a: 1-(2-(4-chlorophenyl)-5-((2-phenylthiazol-4yl)methyl)-1,3,4-oxadiazol-3(2H)-yl) ethanone $\mathrm{C}_{2} \mathrm{H}_{1} \mathrm{CIN} \mathrm{O}_{2}$ S; Yield $65 \%$. m.p. $185-187^{\circ} \mathrm{C}$, MS (El, 70eV): $\mathrm{m}^{2} / \mathrm{z} 399$ ('M+2). ${ }^{1} \mathrm{H}$ NMR (DMSO-d6, $\left.\delta, \mathrm{ppm}\right) \delta: 7.47-7.94$, $9 \mathrm{H}\left(5 \mathrm{H}\right.$ phenyl, $4 \mathrm{H} \mathrm{p}$-Cl-phenyl), 7.3 (s $1 \mathrm{H}$, oxadiazol $\left.\mathrm{C}_{2}\right)$, 7.06 (s $1 \mathrm{H}$, thiazole-5), $4.09\left(\mathrm{~s}, 2 \mathrm{H}, \mathrm{CH}_{2}\right), 2.16(\mathrm{~s}, 3 \mathrm{H}, \mathrm{N}-$ $\left.\mathrm{COCH}_{3}\right)$.

$5 \mathbf{b}: 1$-(2-(4-bromophenyl)-5-((2-phenylthiazol-4yl) methyl)-1,3,4-oxadiazol-3(2H)yl) ethanone $\mathrm{C}_{2} \mathrm{H}_{1} \mathrm{BrN} \mathrm{O}_{2} \mathrm{~S}$; Yield $60 \%$. m.p. $210-211^{\circ} \mathrm{C}$, MS (El, 70eV): $\mathrm{m} / \mathrm{z} 443\left({ }^{3}+2\right)$. ${ }^{1} \mathrm{H}$ NMR (DMSO-d6, $\left.\delta, \mathrm{ppm}\right) \delta: 7.49-8.16$, 9H (5H phenyl, 4H p-Br-phenyl), 7.37 ( $\mathrm{s} 1 \mathrm{H}$, oxadiazol $\mathrm{C}_{2}$ ), 7.06 (s $1 \mathrm{H}$, thiazole-5), $4.04\left(\mathrm{~s}, 2 \mathrm{H}, \mathrm{CH}_{2}\right), 2.26(\mathrm{~s}, 3 \mathrm{H}, \mathrm{N}-$ $\left.\mathrm{COCH}_{3}\right)$.

5c:1-(2-(4-nitrophenyl)-5-((2-phenylthiazol-4yl)methyl)-1,3,4-oxadiazol-3(2H)-yl) ethanone $\mathrm{C}_{2} \mathrm{H}$ N O S; Yield $60 \%$. m.p. $130-132^{\circ} \mathrm{C}$, MS (El, 70eV): $\mathrm{m} /$ z $409^{6}(M+1)$. ${ }^{1 H}$ NMR (DMSO-d6, $\left.\delta, p p m\right) \delta: 7.47-8.19,9 \mathrm{H}$ (5H phenyl, $4 \mathrm{H}$ p-NO-phenyl), 7.34 ( $\mathrm{s} \mathrm{H}$, oxadiazol $\mathrm{C}_{2}$ ), 7.1 (s $1 \mathrm{H}$, thiazole-5), $4.01\left(\mathrm{~s}, 2 \mathrm{H}, \mathrm{CH}_{2}\right), 2.16(\mathrm{~s}, 3 \mathrm{H}, \mathrm{N}-$ $\left.\mathrm{COCH}_{3}\right)$.

5d: 1-(2-(2-phenylthiazol-4-yl)-5-((2-phenylthiazol-4yl)methyl)-1,3,4-oxadiazol-3(2H)-yl) ethanone $\mathrm{C}_{22} \mathrm{H}_{12} \mathrm{~N} \mathrm{O}_{2}$; Yield $55 \%$. m.p. $175-177^{\circ} \mathrm{C}$, MS (El, 70eV): $\mathrm{m}^{2} / \mathrm{z} 447^{4}\left(\mathrm{M}^{2}+1\right)$. ${ }^{1} \mathrm{H}$ NMR (DMSO-d6, $\left.\delta, \mathrm{ppm}\right) \delta: 7-8.16$, $13 \mathrm{H}\left(10 \mathrm{H} 2\right.$ phenyl, $2 \mathrm{H} 2$ thiazole $\mathrm{C}_{5}, 1 \mathrm{H}$ oxadiazole $\left.\mathrm{C}_{2}\right)$, $4.01\left(\mathrm{~s}, 2 \mathrm{H}, \mathrm{CH}_{2}\right), 2.30\left(\mathrm{~s}, 3 \mathrm{H}, \mathrm{N}-\mathrm{COCH}_{3}\right)$.

5e: 1-(2-(2-chlorophenyl)-5-((2-(p-tolyl) thiazol-4yl)methyl)-1,3,4-oxadiazol-3(2H)-yl) ethanone $\mathrm{C}_{2} \mathrm{H}_{1} \mathrm{CIN} \mathrm{O}_{2}$ S; Yield $70 \%$. m.p. $160-165^{\circ} \mathrm{C}$, MS (El, 70eV): $\mathrm{m}^{2} / \mathrm{z} 413(\mathrm{M}+2)$, ${ }^{1} \mathrm{H}$ NMR (DMSO-d6, $\left.\delta, \mathrm{ppm}\right) \delta: 7.26-7.87$, $9 \mathrm{H}$ (4H tolyl, 4H o-Cl-phenyl, $1 \mathrm{H}$, oxadiazol $\left.\mathrm{C}_{2}\right), 7.06(\mathrm{~s} 1 \mathrm{H}$, thiazole-5), $4.06\left(\mathrm{~s}, 2 \mathrm{H}, \mathrm{CH}_{2}\right), 2.34\left(\mathrm{~s}, 3 \mathrm{H}\right.$, tolyl- $\left.\mathrm{CH}_{3}\right), 2.23$ $\left(\mathrm{s}, 3 \mathrm{H}, \mathrm{N}-\mathrm{COCH}_{3}\right)$.

5f: 1-(2-(4-fluorophenyl)-5-((2-(p-tolyl) thiazol-4yl)methyl)-1,3,4-oxadiazol-3(2H)-yl) ethanone $\mathrm{C}_{2} \mathrm{H}_{1} \mathrm{FN}_{3} \mathrm{O}_{2} \mathrm{~S}$; Yield $70 \%$. m.p. 202-204 ${ }^{\circ} \mathrm{C}$, MS (El, 70eV): $\mathrm{m}^{2} / \mathrm{z} 396\left(\mathrm{M}^{2}+1\right)$, ${ }^{1} \mathrm{H}$ NMR (DMSO-d6, $\left.\delta, \mathrm{ppm}\right) \delta:$ 7.22-7.87, 9H (4H tolyl, $4 \mathrm{H}$ p-F-phenyl, $1 \mathrm{H}$, oxadiazol $\left.\mathrm{C}_{2}\right), 7.06(\mathrm{~s} 1 \mathrm{H}$, thiazole-5), $3.98\left(\mathrm{~s}, 2 \mathrm{H}, \mathrm{CH}_{2}\right), 2.34\left(\mathrm{~s}, 3 \mathrm{H}\right.$, tolyl- $\left.\mathrm{CH}_{3}\right), 2.16$ $\left(\mathrm{s}, 3 \mathrm{H}, \mathrm{N}-\mathrm{COCH}_{3}\right)$.

5g: 1-(2-(2-methoxyphenyl)-5-((2-(p-tolyl)thiazol-4yl) methyl)-1,3,4-oxadiazol-3(2H)-yl) ethanone $\mathrm{C}_{2} \mathrm{H}_{3} \mathrm{~N}_{2} \mathrm{O}$ S; Yield $70 \%$. m.p. $175-178^{\circ} \mathrm{C}$, MS (El, 70eV): m/ $z_{408}(M+1)$, ${ }^{1} \mathrm{H}$ NMR (DMSO-d6, $\left.\delta, \mathrm{ppm}\right) \delta: 7.06-7.88,9 \mathrm{H}$ (4H, tolyl, $4 \mathrm{H} \mathrm{OCH}_{3}$-phenyl, $1 \mathrm{H}$, oxadiazol $\mathrm{C}_{2}$ ), 7.00 (s $1 \mathrm{H}$,

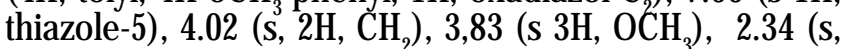
$3 \mathrm{H}$, tolyl- $\left.\mathrm{CH}_{3}\right), 2.22\left(\mathrm{~s}, 3 \mathrm{H}, \mathrm{N}-\mathrm{COCH}_{3}\right)$. 
5h: 1-(2-(2,4-dichlorophenyl)-5-((2-(p-tolyl)thiazol-4yl)methyl)-1,3,4-oxadiazol-3(2H)-yl) ethanone $\mathrm{C}_{2} \mathrm{H}_{1} \mathrm{Cl} \mathrm{N}_{2} \mathrm{O}$ S; Yield $75 \%$. m.p. $160-165^{\circ} \mathrm{C}$, MS (El, 70eV): $\mathrm{m}^{2} \mathrm{z} 447^{2}(M+2)$, ${ }^{3} \mathrm{H}$ NMR (DMSO-d6, $\left.\delta, \mathrm{ppm}\right) \delta: 7.26-7.87$, $6 \mathrm{H}$ (4H, tolyl, 3H o,p-diCl-phenyl, $1 \mathrm{H}$, oxadiazol $\mathrm{C}_{2}$ ), 7.06 (s $1 \mathrm{H}$, thiazole-5), $4.00\left(\mathrm{~s}, 2 \mathrm{H}_{1} \mathrm{CH}_{2}\right), 3,83\left(\mathrm{~s} 3 \mathrm{H}, \mathrm{OCH}_{3}\right), 2.34$ $\left(\mathrm{s}, 3 \mathrm{H}\right.$, tolyl- $\left.\mathrm{CH}_{3}\right), 2.23\left(\mathrm{~s}, 3 \mathrm{H}, \mathrm{N}-\mathrm{COCH}_{3}\right)$.

\section{Anti-Candida Activity}

The synthesized compounds $5 \mathrm{a}-\mathrm{h}$ were screened against the Candida albicans ATCC 90028 fungal strain, by an adapted agar disk diffusion technique using a fungal suspension of 0.5 McFarland density obtained from $24 \mathrm{~h}$ cultures. The compounds were solubilized in dimethylsulfoxide to a final concentration of $1 \mathrm{mg} / \mathrm{mL}$. A volume of $5 \mu \mathrm{L}$ of each tested compound's solution was distributed directly on the solid medium previously seeded with the fungal inocula. The inoculated plates were incubated for $24 \mathrm{~h}$ at $37^{\circ} \mathrm{C}$. Standard antifungal drug, ketoconazole, was also tested under similar conditions.

\section{ADME study}

In order to investigate the potential pharmacokinetic properties of the novel synthesized compounds, an ADME study was performed using Swiss-ADME (www. swissadme.ch).

\section{Molecular docking study}

A comparative molecular docking study was performed using AutoDock Vina [18] against fungal lanosterol $14 \alpha-$ demethylase (PDB: 5V5Z-Candida albicans), respectively against the human one (PDB: 3LD6 - Homo sapiens). Crystal structures of the enzymes were obtained from Protein Data Bank.

Dataset of compounds and the target structures were prepared using the previous reported protocol $[19,20]$. The grid boxes for both targets were configured as cube with sides $x=y=z=28$. Center coordinates of the search space for fungal enzyme were set to $x=-38.49, y=-17.585$, $z=25.505$ and for the human one to $x=40.759, y=2.342$, $z=0.724$. Molecular weight, partition coefficient $(\log P)$ and topological polar surface area (TPSA) were computed using FAF3-Drug [21].

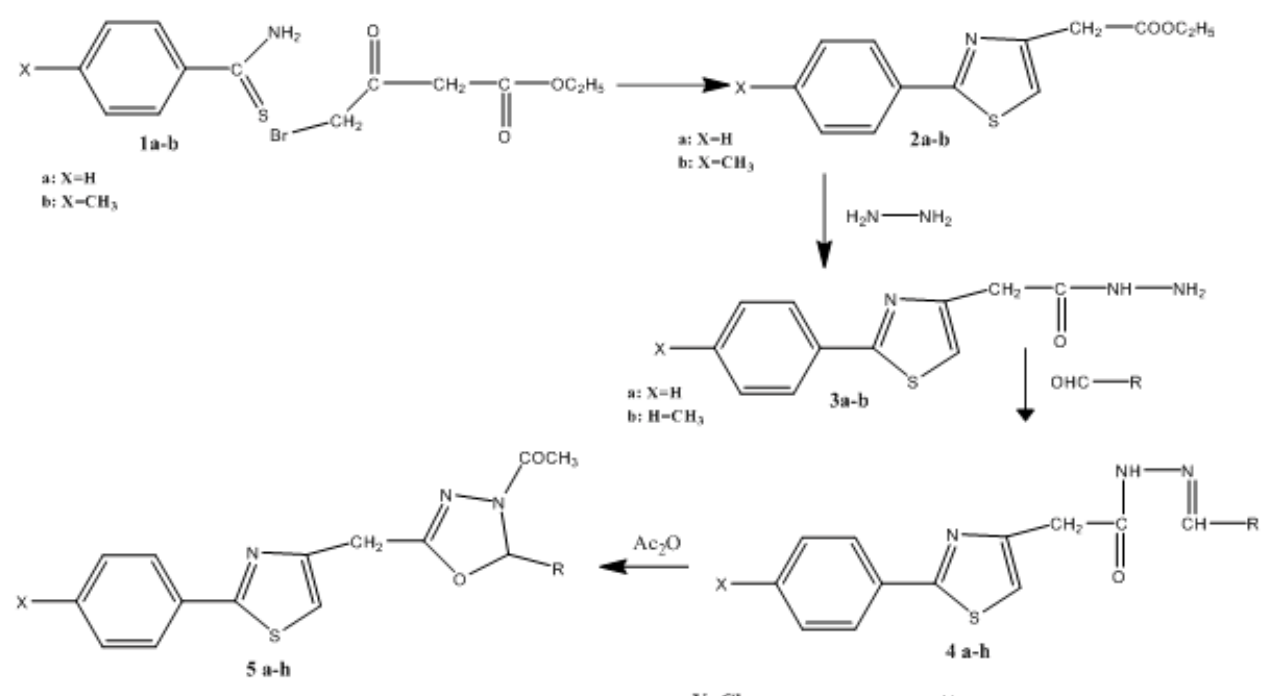

Fig. 1. Chemical synthesis of the target c: $\mathrm{Y}=\mathrm{NO}_{2}$ 4,5e-h: $\mathrm{X}=\mathrm{CH}_{3}, \mathrm{R}=\longrightarrow \begin{aligned} & \mathrm{e}: \mathrm{Y}=\mathrm{Cl}, \mathrm{Y}^{\prime}=\mathrm{H} \\ & \mathrm{f}: \mathrm{Y}=\mathrm{H}, \mathrm{Y}^{\prime}=\mathrm{F} \\ & \mathrm{g}: \mathrm{Y}=\mathrm{OCH}_{3}, \mathrm{Y}=\mathrm{H}\end{aligned}$ h: $\mathrm{Y}=\mathrm{Cl}, \mathrm{Y}^{\prime}=\mathrm{Cl}$
Visualization and analysis of the docking results were performed using UCSF Chimera [22].

\section{Results and discussions \\ Chemistry}

The final compounds ( $5 a-h)$ were obtained by a fourstep (Figure 1), convenient synthetic route. The 2-aryl-1,3thiazole scaffold was easily achieved by a Hantzsch cyclization between appropriate thioamides $\mathbf{1} \mathbf{a}-\mathbf{b}$ and ethyl 4-bromo-3-oxo-butanoate. Applying the hydrazinolysis of the esters $2 \mathbf{a}-\mathbf{b}$ with hydrazine hydrate in absolute ethanol, the 2-(2-arylthiazol-4-yl)acetohydrazides 3a-b were prepared in satisfactory yields. These acetohydrazides, upon condensation with aromatic or heteroaromatic aldehydes, in absolute ethanol, afforded the corresponding hydrazones $4 a-h$. The obtained hydrazones were cyclised into the 1-(2-(aryl)-5-((2-arylthiazol-4-yl) methyl)-1,3,4oxadiazol-3(2H)-yl) ethanones 5a-h (thiazolyl-methylen1,3,4-oxadiazolines derivatives), by refluxing them with acetic anhydride ( fig 1 ).

The structures of the newly synthesized compounds were elucidated by the combined use of ${ }^{\mathrm{H}} \mathrm{H}-\mathrm{NMR}$, mass spectral data and elemental analysis. The ${ }^{1} \mathrm{H}$-NMR spectra of compounds 4a-h showed a singlet signal at $\delta 8.48-8.63$ ppm range corresponding to $\mathrm{CH}$ of the benzylidene group and another singlet signal at $\delta 10.75-11.58 \mathrm{ppm}$ range due to the NH proton, hence confirming the formation of hydrazones. The ${ }^{1} \mathrm{H}$-NMR spectra of compounds $\mathbf{5 a}-\mathbf{h}$ revealed the disappearance of azomethine and hydrazide protons and the occurrence of some new singlet signals at 7.2 - $7.6 \mathrm{ppm}(1 \mathrm{H})$ indicating $\mathrm{CH}$ resonance of the oxadiazoline ring and at $2.16-2.3 \mathrm{ppm}(3 \mathrm{H})$, which were attributed to the acetyl group protons $\left(\mathrm{N}-\mathrm{COCH}_{3}\right.$ - in the 4 position of the oxadiazoline ring). MS findings were in accordance with the theoretical molecular formula of the compounds.

\section{Antifungal Activity}

Determination of Inhibition Zone Diameters

The synthesized compounds $5 a-h$ were screened against the fungal strain of Candida albicans ATCC 90028. The obtained results are presented in Table 1, compared

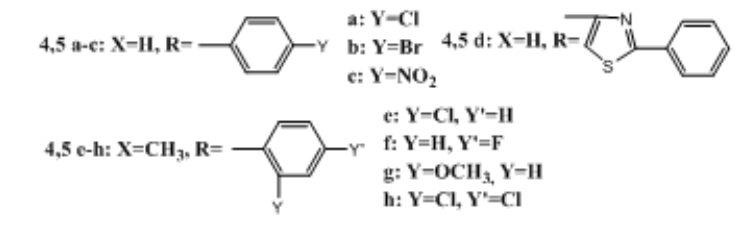

Table 1

ANTI-CANDIDA ACTIVITY OF THE TESTED COMPOUNDS

\begin{tabular}{|l|l|}
\hline Compound & $\begin{array}{l}\text { Inhibition Zone } \\
\text { Diameter (mm) }\end{array}$ \\
\hline $5 \mathrm{a}$ & 29 \\
\hline $5 \mathrm{~b}$ & 24 \\
\hline $5 \mathrm{c}$ & 22 \\
\hline $5 \mathrm{~d}$ & 20 \\
\hline $5 \mathrm{e}$ & 22 \\
\hline $5 \mathrm{f}$ & 24 \\
\hline $5 \mathrm{~g}$ & 18 \\
\hline $5 \mathrm{~h}$ & 22 \\
\hline Ketoconazole & 24 \\
\hline
\end{tabular}




\begin{tabular}{|l|l|l|l|}
\hline Compound & $\begin{array}{l}\text { Molecular } \\
\text { weight }(\mathrm{MW})\end{array}$ & $\begin{array}{l}\text { Partition } \\
\text { coefficient (LogP) }\end{array}$ & $\begin{array}{l}\text { Topological } \\
\text { polar surface } \\
\text { area (TPSA) }\end{array}$ \\
\hline 5a & 397.88 & 4.23 & 83.03 \\
\hline 5b & 442.33 & 4.3 & 83.03 \\
\hline $\mathbf{5 c}$ & 408.43 & 3.44 & 128.85 \\
\hline $\mathbf{5 e}$ & 446.54 & 4.34 & 124.16 \\
\hline $\mathbf{5 h}$ & 411.9 & 4.6 & 83.03 \\
\hline $\mathbf{5 e}$ & 395.45 & 4.07 & 83.03 \\
\hline $\mathbf{5 f}$ & 407.49 & 3.94 & 92.26 \\
\hline $\mathbf{5 h}$ & 446.35 & 5.23 & 83.03 \\
\hline
\end{tabular}

Table 2

MOLECULAR WEIGHT, PARTITION COEFFICIENT AND TOPOLOGICAL POLAR SURFACE AREA OF COMPOUNDS5a-h with ketoconazole. The solventused to prepare the solutions of the synthesized compounds, dimethylsulfoxide (DMSO), exhibited no inhibitory activity on the fungal strain used in the study.

Analyzing the results, we can observe that most of the tested compounds showed inhibition zone diameters inferior to or equal to ketoconazole, except the compound 5 a that had an inhibition zone diameter superior to ketoconazole used as a standard drug. Concerning the relationships between the structure of the compounds and the anti-Candida activity, we observed that the compounds substituted with halogens $(\mathrm{Cl}, \mathrm{Br}, \mathrm{F})$ in the para position of the oxadiazoline $\mathrm{C}_{2}$-phenyl ring showed the biggest inhibition zone diameters (24-29 mm). Other type of substituents such as methoxy, nitro or halogens in orto position seems to be less favorable for the antifungal action.

\section{Theoretical Calculation of ADME Parameters}

A computational study for the prediction of the ADME properties of the compounds $5 a-h$ was performed, and the results are shown in Table 2 . Topological polar surface area (TPSA) and logP are descriptors that are known to correlate well with passive molecular transport through membranes and thus have influence on metabolism, cell penetration, and bioavailability.

According to the Lipinski's rule of 5[23], poor absorption or permeation is more likely when the molecular weight (MW) is greater than 500, the calculated Log P is greater than 5 and TPSA values are 140 or more. Our results indicated that the majority of compounds (exception compound 5 h- Log $P$ greater than 5) have good pharmacokinetic properties.

Molecular docking study

In order to provide an explanation for the mechanism of action of the synthesized compounds against $C$. albicans strain, docking studies were performed using AutoDock Vina software.

With the aim to evaluate and compare the binding affinity of our compounds to the fungal and the human lanosterol $14 \alpha$-demethylase, the synthesized compounds $5 a-h$ and ketoconazole, as a control inhibitor, were docked into the active site of both fungal and human lanosterol $14 \alpha$ demethylase. The predicted affinity of compounds to the active site of both enzymes and the consequent inhibition constant (ki) are presented in Table 3. Inhibition constant (ki) was calculated based on the computed binding affinity energy $(\Delta G)$ using the formula: $K_{i}=e^{\frac{\Delta G \times 1000}{R \times T}}$. $R$ represents the Regnault constant $=1,98719 \frac{\mathrm{kcal}}{\mathrm{Kx} \mathrm{mol}}$ and $\mathrm{T}$ $=298.15 \mathrm{~K}$.

We have also calculated the fungal/human inhibition ratio (Table 3 ) in order to identify the compounds that inhibit selectively fungal lanosterol $14 \alpha$-demethylase enzyme.

Analyzing the results of the docking study we identified three compounds ( $\mathbf{5 a}, \mathbf{5 b}$ and $\mathbf{5 f}$ ) that have better fungal/ human inhibition ratio than ketoconazole meaning a superior selectivity for the fungal enzyme. We then focused on these compounds, while eliminating the others due to the lack of selectivity towards the fungal enzyme. The eliminated compounds had a less significant antifungal activity as determined by the diameters of the inhibition zone (Table 1). Selective enzyme inhibition is crucial for the safety profile of an antifungal drug. Ketoconazole is a highly effective antimycotic but it's use has been restricted to topical formulations only as a result of liver toxicity caused by inhibition of the human lanosterol $14 \alpha-$ demethylase. From this perspective obtaining new compounds that are selective towards the fungal enzyme is crucial for the efficiency and, above all, safety profile.

Figure 2 consists of the representation of the binding patterns into the active site of lanosterol demethylase for the ketoconazole, used as the reference antifungal drug, and for compounds $\mathbf{5 a}, \mathbf{5 b}$ and $\mathbf{5 f}$.

The docking results showed that our compounds did not covalently interact with the heme from the active site of lanosterol $14 \alpha$-demethylase, like classic antifungal azoles (e.g. ketoconazole). However, they interact with the amino acids located in the access channel to the enzyme's active site, such as: LEU376, HIS377, LEU87, VAL234, PHE 233 and PHE463. As a result, we can assume that the newly synthesized compounds act as noncompetitive inhibitors of the enzyme. This supposition implies that a slightly different mechanism of action is in play (compared to classic antifungal azoles) which could

\begin{tabular}{|l|l|l|l|l|l|}
\hline \multirow{3}{*}{ Compound } & \multicolumn{2}{|l|}{$\begin{array}{l}\text { Candida albicans } \\
\text { (PDB: 5V5Z) }\end{array}$} & $\begin{array}{l}\text { Homo } \\
\text { (PDB: 3LD6) }\end{array}$ & \multirow{2}{*}{$\begin{array}{l}\text { Fungal / human } \\
\text { inhibition ratio }\end{array}$} \\
\cline { 2 - 6 } & $\begin{array}{l}\text { Binding affinity } \\
\text { (kcal/mol) }\end{array}$ & $\begin{array}{l}\text { Inhibition } \\
\text { constant (nM) }\end{array}$ & $\begin{array}{l}\text { Binding affinity } \\
\text { (kcal/mol) }\end{array}$ & $\begin{array}{l}\text { Inhibition } \\
\text { constant (nM) }\end{array}$ & \\
\hline $\mathbf{5 a}$ & -11.6 & $\mathbf{3 . 1 4}$ & -11.2 & 6.17 & 0.51 \\
\hline $\mathbf{5 b}$ & -11.4 & $\mathbf{4 . 4 0}$ & -11.2 & 6.17 & 0.71 \\
\hline $\mathbf{5 c}$ & -11.6 & 3.14 & -11.5 & 3.72 & 0.84 \\
\hline $\mathbf{5 d}$ & -10.9 & 10.24 & -12.2 & 1.14 & 8.97 \\
\hline $\mathbf{5 e}$ & -11.6 & 3.14 & -11.6 & 3.14 & 1.00 \\
\hline $\mathbf{5 f}$ & -11.9 & 1.89 & -11.7 & $\mathbf{2 . 6 5}$ & 0.71 \\
\hline $\mathbf{5 g}$ & -11.2 & 6.17 & -11.3 & 5.21 & 1.18 \\
\hline $\mathbf{5 h}$ & -11.8 & 2.24 & -11.7 & 2.65 & 0.84 \\
\hline Ketoconazole & $-\mathbf{1 2 . 3}$ & $\mathbf{0 . 9 5}$ & -12.26 & $\mathbf{1 . 0 4}$ & $\mathbf{0 . 9 1}$ \\
\hline
\end{tabular}

Table 3

PREDICTED BINDING AFFINITY AND THE CONSEQUENT

INHIBITION CONSTANT OF COMPOUNDS5a-h TO FUNGAL AND HUMAN LANOSTEROL $14 \alpha-$ DEMETHYLASE 


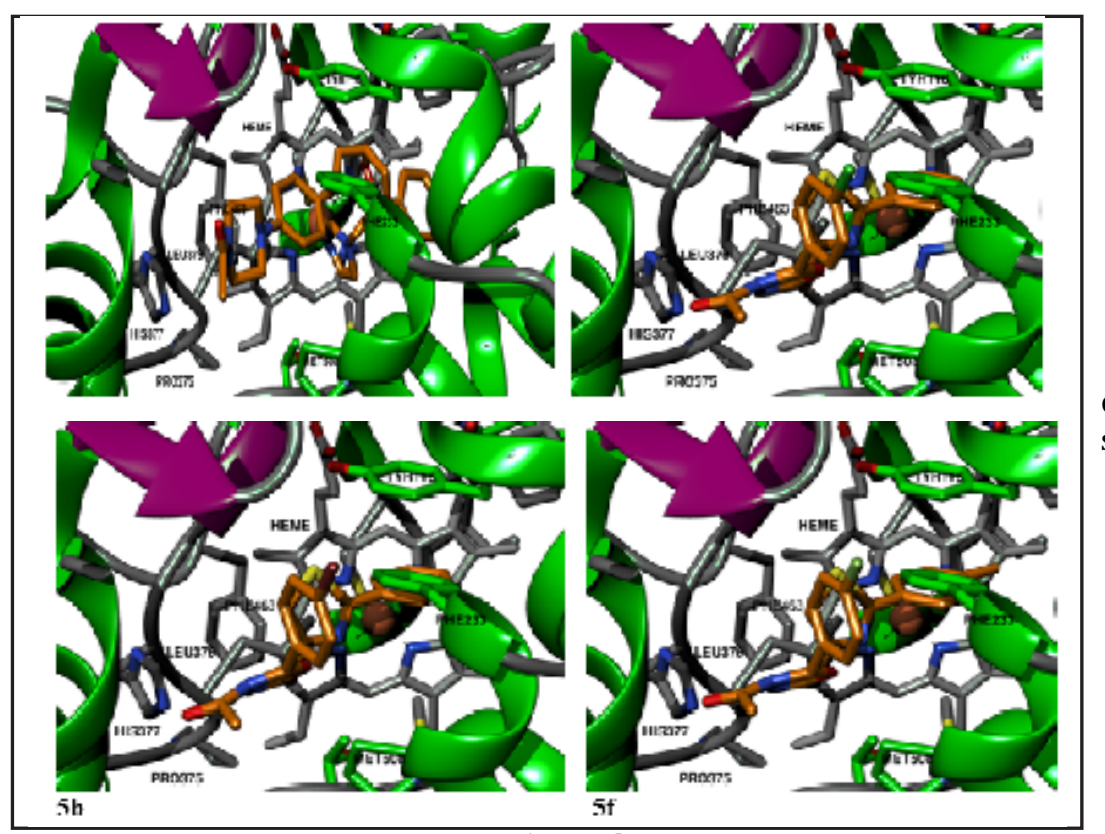

Fig. 2. The proposed binding mode of compounds $5 \mathrm{a}, 5 \mathrm{~b}$ and $5 f$ compared to ketoconazole (Fungal lanosterol $14 \alpha$ demethylase á helices are depicted in green, $b$ sheets in magenta and carbon atoms from coils in gray. Ligands carbon atoms are depicted in orange. All significant nitrogen atoms are depicted in blue and oxygen atoms in red.)

promise a protection against fungal resistance mechanisms and also a reduced hepatic toxicity [8].

The synthesized compounds comprise two different substitutions as phenyl or tolyl on C-2 position of thiazole ring. Docking results showed that this modification in structure did not cause a significant change in the interaction manner. For a significant change a substituent larger than methyl should be introduced.

The presence of the halogen atoms in the para position of the terminal aromatic ring leads to a better molecular lipophilicity, with no significant changes in target interaction. Substitution with halogen atoms in other positions, such as meta or orto would result only in pharmacokinetic changes, because there are no amino acid residues in the proximity for potential interactions.

The oxadiazoline ring acts more like a hinge, than a potential pharmacophore. No polar interactions are made by atoms from this ring, the only vicinal amino acid residue being Leu376. However, the oxadiazoline ring carries the acetyl residue, important for polar contact with His377 in all molecules.

\section{Conclusions}

In the current work, a series of new thiazolyl-methylenoxadiazolines (5a-h) were synthesized and evaluated for their in vitro anti-Candida activities. Results of the antifungal study indicated that compound 5 a has a significant anticandidal activity, better than the standard ketoconazole. Furthermore, docking studies showed that these compounds interact with the amino acids from the access channel to the active site of the lanosterol $14 \alpha$-demethylase and not with the heme moiety, as do classical antifungal azoles. As such, these compounds could have the advantage of a slightly different mechanism of action that would translate into a reduced risk for the emergence of antifungal resistance and an improved safety profile. ADME predictions also support the druggability of these compounds.

As a result it can be stated that the synthesized compounds should be further developed in order to identify new antifungal agents with higher potency and tolerably.

\section{References}

1.SANGUINETT, M., POSTERARO, B., LASS-FLORL, C., Mycoses, 58, no. 2, 2015, p. 2.

2.BERKOW, E., LOCKHART, S., Infect. Drug. Resist., 10, 2017, p. 237.
3.SCORZONI, L., DE PAULA E SILVA, A., MARCOS, C., ASSATO, P., DE MELO, W., DE OLIVEIRA, H., COSTA-ORLANDI, C., MENDES-GIANNINI M., FUSCO-ALMEIDA, A., Front. Microbiol., 8, no. 36, 2017, p. 1. 4.PIANALTO, K., ALSPAUGH, A., J. Fungi, 2, no. 26, 2016, p. 1. 5.WANI, M., AHMAD, A., SHIEKH, R., AL-GHAMDI, K., SOBRAL, A., Bioorg. Med. Chem., 23, 2015, p. 4172.

6.LEVENT, S., KAYA CAVUTODLU, B., SAĐLIK, B.N., OSMANIYE, D., ACAR CEVIK, U., ATLI, O., OZKAY, Y., KAPLANCIKLI, Z.A., Molecules, 22, no. 11 2017, p. 1.

7.CAN, N.O., CEVIK, U.A., SADLIK, B.N., LEVENT, S., KORKUT, B., OZKAY, Y., KAPLANCIKLI, Z.A., KOPARAL, A.S., J ournal of Chemistry, 2017, 2017, p.1.

8.STANA, A., ENACHE, A., VODNAR, D.C., NASTASA, C., BENEDEC, D., IONU, I., LOGIN, C., MARC, G., ONIGA, O., TIPERCIUC, B., Molecules 21, 2016, p. 1595.

9.CARRADORI, S., SECCI, D., BOLASCO, A., RIVANERA, D., MARI, E., ZICARI, A., LOTTI, L., BIZZARRI, B., Eur J Med Chem. 65, 2013, p.102. 10.MAILLARD, L., BERTOUT, S., QUINONERO, O., AKALIN, G., TURANZITOUNI, G., FULCRAND, P., DEMIRCI, F., MARTINEZ, J., MASURIER, N., Bioorg. Med. Chem., 23 no. 6, 2013, p.1803.

11.MELEDDU, R., DISTINTO, S., CIRILLI, R., ALCARO, S., YANEZ, M., SANNA, M., CORONA, A., MELIS, C., BIANCO, G., MATYUS, P., COTTIGLIA, F., MACCIONI, E., J. Enzyme Inhib. Med. Chem., 31, no. 6, 2016, p.1672.

12.YURTTAS, L., OZKAY, Y., GENCER, H., ACAR, U., J ournal of Chemistry, 2015, 2015, p.1.

13.KHALILULLAH, H., KHAN, S., NOMANI,S., AHMED, B., Arab. J. Chem, 9 no. 2, 2016, p.1029.

14.WILSON, P., YUSUF S., IJPSR, 7 no. 5, 2016, p.2074.

15.ONIGA, S., DUMA, M, ONIGA, O., TIPERCIUC, B., PIRNAU, A., ARANICIU, C., PALAGE, M., Farmacia, 63 no. 2, 2015, p.171

16.ARANICIU, C., ONIGA, S., ONIGA, O., PALAGE, M., CHIFIRIUC, M.C., MARUTESCU, L., Farmacia, 63, no. 1 2015, p.40.

17.ONIGA, S., ARANICIU, C., PALAGE, M., STOICA, C., CHIFIRIUC M.C., MARUTESCU, L.,Rev. Chim. (Bucharest), 67 no. 3, 2016, p.426.

18.TROTT, O., OLSON, A.J ., J. Comput. Chem., 31, no. 2, 2010, p.455. 19.STOICA, C.I., MARC, G., PIRNAU, A., VLASE, L., ARANICIU, C., ONIGA, S., PALAGE, M., ONIGA, 0., Farmacia, 64, no. 3, 2016, p.390. 20.MARC, G., IONU, I., PIRNAU, A., VLASE, L., VODNAR, D.C., DUMA, M., TIPERCIUC, B., ONIGA, O., Farmacia, 65, no. 3, 2017, p.414.

21.LAGORCE, D., SPERANDIO, O., BAELL, J., MITEVA, M., VILLOUTREIX, B., Nucleic Acids Res., 43, 2015, p.200.

22.PETTERSEN, E.F., GODDARD, T.D, HUANG C.C., COUCH, G.S, GREENBLATT, D.M, MENG, E.C, FERRIN, T.E., J. Comput. Chem., 25, no. 13, 2004, p.1605.

23.LIPINSKI, C.A. LOMBARDO, F., DOMINY B.W., FEENEY, P.J . Adv. Drug Deliv. Rev., 23, 1997, p.3.

Manuscript received: 15.12 .2018

3526

http://www.revistadechimie.ro 